\title{
Reflections, Analysis, and Significance for Human Ecology of Pope Francis's Encyclical Letter Laudato Si': On Care for Our Common Home
}

\author{
Robin van Tine' \\ Department of Science and Mathematics \\ Saint Leo University, Virginia, United States
}

\section{Abstract}

Pope Francis's significant and timely environmental encyclical is reviewed, analyzed, and reflected upon from a human ecology perspective. The analysis includes comparison with various ecological, philosophical, sociological, ethical, theological, and economic schools of thought. His powerful and influential prose and poetry are sampled and savored with respect to their potential impact on solutions for our current grave existential global environmental crisis. His call for an ecological spiritual awakening is interpreted from both religious and secular points of view. Historical relationships between Catholicism and environmental thought are explored. Application to the field of human ecology is considered.

Keywords: climate change, the commons, ecological economics, ecological limits, ecology, ecophilosophy, ecotheology, environmental ethics, global warming, human ecology, Pope Francis, sustainability

Everything is related, and we human beings are united as brothers and sisters on a wonderful pilgrimage, woven together by the love God has for each of his creatures and which also unites us in fond affection with brother sun, sister moon, brother river and mother earth. (Pope Francis, Laudato Si)

\section{Introduction}

For most of my professional life I have been trying to understand why we humans continue to destroy our own life support systems even though we know that we are doing so! The science is conclusive, but governmental and industrial policies, world views and individual lifestyles in the developed world are in opposition (van Tine, 2000). Pope Francis may have answered some of these questions and provided

1 Author contact: robin.vantine@saintleo.edu 
some insightful solutions in his powerful and comprehensive encyclical, Laudato Si' (Francis, 2015). It is a timely, highly significant, and influential work from one of the world's most important moral authorities, considering the magnitude of the environmental crises of its own making that humanity is now facing. It is a treatise on human ecology, a paean to environmental ethics, a plea for eco-spiritual awakening, and a call to action.

"Praise be to you, my Lord, through our Sister, Mother Earth, who sustains and governs us," Pope Francis begins the encyclical, quoting from his namesake's Canticle of the Creatures (Francis of Assisi, 1914), and reminding us that "our common home is like a sister with whom we share our life and a beautiful mother who opens her arms to embrace us" ( 1$).^{2}$ He goes on to forcefully write that "This sister now cries out to us because of the harm we have inflicted on her by our irresponsible use and abuse"- a powerful indictment of our failure to live in harmony with creation!

He connects "a violence in our hearts" to the "sickness evident in the soil, in the water, in the air and in all forms of life." Francis reminds us that our very bodies are made up of Earth's elements, that "we breathe her air" and that we "receive life ... from her waters" ( 2). Or, as Seed et al. (2007) put it, "We are the rocks dancing." He's certainly not the first pope to remind us that we are damaging creation (van Tine, 2015), but with this encyclical he becomes the most forceful pontifical environmental advocate at this critical time in human history.

As cited by Francis, Paul VI wrote of an "ecological catastrophe under the effective explosion of industrial civilization." "Due to an ill-considered exploitation of nature, humanity runs the risk of destroying it and becoming in turn a victim of this degradation," and he called for "radical change in the conduct of humanity" ( $₫ 4)$. $\mathrm{He}$ also wrote about the human interdependency with all of nature. John Paul II wrote that humans seem "to see no other meaning in their natural environment than what serves for immediate use and consumption" and in 2001 called for a "global ecological conversion". ${ }^{4}$ In January of 2010, Roman Catholic Pope Benedict XVI stated "no less troubling are the threats arising from the neglect—if not downright misuse - of the earth and the natural goods that God has given us." He went on to write "economic activity needs to consider the fact that "every economic decision has a moral consequence' and thus show increased respect for the environment" and concluded "If you want to cultivate peace, protect creation". ${ }^{5}$ Pope Benedict XVI also wrote forcefully as an obvious systems thinker, about our interconnectedness"the book of nature is one and indivisible," and that the natural environment has been "gravely damaged" by our irresponsible behavior (Benedict XVI, 2014).

\footnotetext{
Note: $\uparrow$ is used throughout to refer to the paragraph number of Pope Francis's encyclical, Laudato Si'. Address to FAO on the 25th Anniversary of Its Institution (16 November 1970), 4: AAS 62 (1970), 833. John Paul II, Redemptor Hominis (encyclical letter, 4 March 1979), 15: AAS 71 (1979), 287.

Benedict XVI, Message for the 2010 World Day of Peace, retrieved from w2.vatican.va/content/benedict-xvi/ en/messages/peace/documents/hf_ben-xvi_mes_20091208_xliii-world-day-peace.html
} 
Benedict held that "Man does not create himself. He is spirit and will, but also nature" (as quoted by Pope Francis, ๆ 6). See van Tine (2015) for a detailed analysis of Pope Benedict's book, The Garden of God.

Francis, writing plainly and forcefully about the seriousness of "the destruction of the human environment" ( 5) as a moral issue, quotes Bartholomew, Greek Orthodox patriarch:

For human beings ... to destroy the biological diversity of God's creation; for human beings to degrade the integrity of the earth by causing changes in its climate, by stripping the earth of its natural forests or destroying its wetlands; for human beings to contaminate the earth's waters, its land, its air, and its life-these are sins ... to commit a crime against the natural world is a sin against ourselves and a sin against $\operatorname{God}^{6}($ ( 8).

The Southern Baptist Convention, in a statement titled "Humans Must Care for Creation and Take Responsibility for Our Contributions to Environmental Degradation," states "There is undeniable evidence that the earth can be damaged by human activity ... We believe that human activity is mixed in its impact on creation-sometimes productive and caring but often reckless, preventable and sinful." It goes on to state, "We must care about environmental and climate issues because of our love for God ... This is not our world, it is God's. Therefore, any damage we do to this world is an offense against God Himself. We share God's concern for the abuse of His creation" (Southern Baptist Convention, n.d.).

Pope Francis refers frequently, not surprisingly, to his namesake, Francis of Assisi, stating that "Francis helps us to see that an integral ecology calls for openness to categories which transcend the language of mathematics and biology" (\$11). The phrase "integral ecology" is used by this and other popes to refer to the familiar academic human ecology concept that human welfare should be included in our considerations of environmental health-it's not just about science, it includes social and environmental justice.

Pope Francis also points out the great importance of Saint Francis's sense of awe and wonder for nature and our interdependency with it:

If we approach nature and the environment without this openness to awe and wonder, if we no longer speak the language of fraternity and beauty in our relationship with the world, our attitude will be that of masters, consumers, ruthless exploiters, unable to set limits on their immediate needs. By contrast, if we feel intimately united with all that exists, then sobriety and care will well up spontaneously ... [creating] ... something much more radical: a refusal to turn reality into an object simply to be used and controlled ( $₫ 11)$.

6 Address in Santa Barbara, California (8 November 1997); cf. Chryssavgis (2012). 
Saint Francis "asked that part of the friary garden always be left untouched, so that wild flowers and herbs could grow there" ( $\$ 12)$, perhaps encouraging future monks to experience awe and wonder. This is reminiscent of Rabbi Abraham Heschel's concept of "radical awe" as well:

The greatest hindrance to ... awareness is our adjustment to conventional notions, to mental clichés. Wonder or radical amazement, the state of maladjustment to words and notions, is therefore a prerequisite for an authentic awareness of that which is (Heschel, 1976).

Pope Francis appeals to us to consider the fact that "Young people demand change. They wonder how anyone can claim to be building a better future without thinking of the environmental crisis and the sufferings of the excluded" (\$13). He points out "the intimate relationship between the poor and the fragility of the planet, the conviction that everything in the world is connected, the critique of new paradigms and forms of power derived from technology, the call to seek other ways of understanding the economy and progress, the value proper to each creature, the human meaning of ecology" and "the throwaway culture" (\$16).

\section{What is happening to our common home?}

Pope Francis warns us:

our common home is falling into serious disrepair ... [and] we can see signs that things are now reaching a breaking point, due to the rapid pace of change and degradation; these are evident in large-scale natural disasters as well as social and even financial crises, for the world's problems cannot be analyzed or explained in isolation (\$61).

$\mathrm{He}$ is a great proponent of holistic thinking regarding the ecosphere. He declares that "The climate is a common good, belonging to all and meant for all” (\$23), but "this century may well witness extraordinary climate change and an unprecedented destruction of ecosystems, with serious consequences for all of us." It is a "global problem with grave implications: environmental, social, economic, political and for the distribution of goods. It represents one of the principal challenges facing humanity in our day. Its worst impact will probably be felt by developing countries" ( (25). Accepting the tenets of climate scientists without reservation and reiterating many of them, Pope Francis's encyclical reads like an environmental science or human ecology textbook in many places. What can it mean when a global religious leader speaks like a scientist while many members of the United States Congress deny science?

The pope proclaims that "The earth, our home, is beginning to look more and more like an immense pile of filth" ( $\mathbf{1} 21)$, as did gaeologian, Catholic priest, and cultural historian Thomas Berry in his seminal book, The Great Work, when he stated "Our 
quest for wonderworld is creating a waste-world" (Berry, 2000). Both agree that most of our environmental problems are at least partially results of our throwaway culture. "Who turned the wonderworld of the seas into underwater cemeteries bereft of colour and life?"7 Francis quotes the Catholic Bishops' Conference of the Philippines ( $₫$ 41), declaring:

the degree of human intervention, often in the service of business interests and consumerism, is actually making our earth less rich and beautiful, ever more limited and grey, even as technological advances and consumer goods continue to abound limitlessly. We seem to think that we can substitute an irreplaceable and irretrievable beauty with something which we have created ourselves ( $($ 34).

"Never have we so hurt and mistreated our common home as we have in the last two hundred years" ( 153 ).

He stresses over and over again that we have exceeded critical ecological limits, for example:

it is not possible to sustain the present level of consumption in developed countries and wealthier sectors of society, where the habit of wasting and discarding has reached unprecedented levels. The exploitation of the planet has already exceeded acceptable limits and we still have not solved the problem of poverty (\$ 27).

The XIV Dalai Lama would agree:

But now human use, population, and technology have reached that certain stage "where Mother Earth no longer accepts our presence with silence". In many ways she is now telling us, "My children are behaving badly," she is warning us that there are limits to our actions (Dalai Lama XIV, n.d.).

The plight of the poor is always front and center in Francis's concerns. To him, environmental justice and social justice issues are part and parcel of our selfish quest for unlimited profits and greed for ever higher levels of consumption"The human environment and the natural environment deteriorate together; we cannot adequately combat environmental degradation unless we attend to causes related to human and social degradation” ( $\$$ 48). Francis claims that the problems of the poor are treated as merely "collateral damage ... frequently, we find beautiful and carefully manicured green spaces in so-called 'safer' areas of cities, but not in the more hidden areas where the disposable of society live" ( 145 ), in what Lerner (2010) calls "sacrifice zones." This is both an environmental injustice and social injustice, "we have to realize that a true ecological approach always becomes a social approach; it must integrate questions of justice in debates on the environment, so as to hear both the cry of the earth and the cry of the poor" ( 49). For example, Francis declares that "access to safe drinkable water is a basic and universal human

7 Catholic Bishops' Conference of the Philippines, pastoral letter "What Is Happening to Our Beautiful Land?" (January 29, 1988). 
right, since it is essential to human survival and, as such, is a condition for the exercise of other human rights" ( 130 ). Access to water should not be commodified! This is the same approach that academic human ecology takes. The pope appears to agree with the conclusions of Garrett Hardin's seminal piece, "The Tragedy of the Commons" (Hardin, 1968).

"The problem is that we still lack the culture needed to confront this crisis" ( 953 ). We need a paradigm shift! A rapid one! Francis declares:

the establishment of a legal framework which can set clear boundaries and ensure the protection of ecosystems has become indispensable; otherwise, the new power structures based on the techno-economic paradigm may overwhelm not only our politics but also freedom and justice ( $\$$ 53).

He suggests that "rapid and constant change [is] not necessarily geared to the common good or to integral and sustainable human development" (\$ 18) and that we have "an irrational confidence in progress and human abilities" ( 1 19). "The growth of the past two centuries has not always led to an integral development and an improvement in the quality of life" ( 9 46), despite what those of us in the first world might believe.

Francis points out that technological and business solutions usually miss the "mysterious" interdependent web of existence of which we are a part, perhaps solving a single problem but causing many others. The pope declares that all of life, including ourselves, is interdependent and worthy of respect. "Because all creatures are connected, each must be cherished with love and respect, for all of us as living creatures are dependent on one another" (\$ 42).

Pope Francis gets at the crux of the basic environmental problem of modern technological civilization when he states:

We have not yet managed to adopt a circular model of production capable of preserving resources for present and future generations, while limiting as much as possible the use of non-renewable resources, moderating their consumption, maximizing their efficient use, reusing and recycling them (\$ 22).

This is certainly a major goal of environmental science and human ecology, as well as being resonant with the tradition of certain Native American peoples to require the consideration of the impact of all current decisions on the Seventh Generation forward (Lyons, 1994).

The pope decries the tragic rise in refugees fleeing poverty caused by environmental degradation, and the fact that they are not considered refugees, but economic migrants. They are also part of the sacrifice zones that are caused by rampant industrial and commercial activities driven purely by the profit motive with little or no consideration for the lives of people or their ecosystems. The pope suggests 
that "such effects will continue to worsen if we continue with current models of production and consumption" ( 126 ), stressing, in essence, that continuing with "business as usual" will be disastrous. The rapid changes caused by global warming are expected to result in millions of climate refugees, in the not-too-distant future, fleeing drought, flood, famine, and ecological collapse caused by the unfettered burning of fossil fuels for centuries.

Francis decries the current global economic system, writing "the earth's resources are ... being plundered because of short-sighted approaches to the economy, commerce and production" ( 32). According to the pope, all creatures have intrinsic value and "It is not enough ... to think of different species merely as potential 'resources' to be exploited, while overlooking the fact that they have value in themselves. The great majority become extinct for reasons related to human activity. We have no such right" ( 933$)$. It is expected that about half of all known species will be extinct by the end of the twenty-first century due to the activities of technological human civilization.

People may well have a growing ecological sensitivity but it has not succeeded in changing their harmful habits of consumption which, rather than decreasing, appear to be growing all the more ... An outsider looking at our world would be amazed at such behaviour, which at times appears self-destructive ( $(55)$.

This idea has been the central focus of my academic work for decades. The selfdestructive nature of current practices is incomprehensible.

The pope claims that we willfully refuse to see clearly what is happening so that we can continue with our destructive lifestyles, and suggests:

such evasiveness serves as a licence to carrying on with our present lifestyles and models of production and consumption. This is the way human beings contrive to feed their self-destructive vices: trying not to see them, trying not to acknowledge them, delaying the important decisions and pretending that nothing will happen ( 159 ).

This is a great social dilemma for the development of a sustainable world, as recognized by Garrett Hardin nearly half a century ago (Hardin, 1968). ${ }^{8}$ Upton Sinclair once wrote, "It is difficult to get a man to understand something when his salary depends on his not understanding it" (Sinclair, 1994, p. 109). Pope Francis would extend that to our entire culture: "We can be silent witnesses to terrible injustices if we think that we can obtain significant benefits by making the rest of humanity, present and future, pay the extremely high costs of environmental deterioration” ( 9 36). He laments our shortsightedness and greed, explaining:

Caring for ecosystems demands far-sightedness, since no one looking for quick and easy profit is truly interested in their preservation. But the cost of the damage caused by such selfish lack of concern is much greater than the economic benefits to be obtained ( $\$ 36$ ).

8 See Osbaldiston and Sheldon (2002) for a thorough discussion of this idea. 
Once again we are reminded of caring for the Seventh Generation (Lyons, 1994). Perhaps the recent international climate change accords in Paris, signed by most nations of the world, are the beginning of a global attempt to start facing reality and the start of serious actions to change our destructive ways. We shall see.

Not surprisingly, due to Catholic teachings on birth control, Pope Francis excludes population growth as the significant environmental problem that it is. But he does make a valid point that the issue can be used as a subterfuge to obfuscate the current pattern of unfair distribution of resources.

To blame population growth instead of extreme and selective consumerism on the part of some, is one way of refusing to face the issues. It is an attempt to legitimize the present model of distribution, where a minority believes that it has the right to consume in a way which can never be universalized, since the planet could not even contain the waste products of such consumption ( $(50)$.

Extreme consumption by the profligate few is part of a causal link that affects the poor in less-developed countries. It is impossible for everyone on Earth to consume and produce waste at the levels of the affluent-it would violate the laws of physics and ecology. But, despite the church's stance against birth control, population growth is an important factor that must be considered if sustainability is ever to be achieved.

Pope Francis speaks powerfully about the morality of food waste: "whenever food is thrown out it is as if it were stolen from the table of the poor" ( $\$ 50)$, quoting Catholic teachings. According to the United Nations Environment Programme, around 3040 percent of all food in the United States is wasted. "Every year, consumers in rich countries waste almost as much food (222 million tonnes) as the entire net food production of sub-Saharan Africa (230 million tonnes)" (FAO, n.d.).

He points out that disproportionate use of resources by the few, mostly in the industrialized North, results in severe local damages in poor communities where the extraction of these resources mostly occurs. Paradoxically, waste and toxic materials are sent in the opposite direction, causing still more damage to those same poor communities-sacrifice zones. "Often the businesses which operate this way are multinationals. They do here what they would never do in developed countries" ( 51). He also decries the unfair and ironic devastating effects of global climate change "caused by huge consumption on the part of some rich countries" and felt most severely by the less-developed communities and countries that have not benefited from fossil fuel-powered industrialization. Great profits are earned by the multinationals at the expense of "the commons," and by the continuous creation of additional sacrifice zones. Corporations don't pay the costs of what neoclassical economists call externalities - poisoned air, water, soil, destabilized climate, loss of biodiversity, species extinction, human health, destruction of the commons. Neither are those costs included in the price of goods and services; therefore there is no incentive for consumers or businesses to operate in ways that are harmonious with 
nature and human health. Lack of this full-cost pricing allows for great profits for the few while causing the many to suffer from the degradation of the ecospherethe commons for all beings, including humans.

Pope Francis forcefully explains that "the foreign debt of poor countries has become a way of controlling them, yet this is not the case where ecological debt is concerned" ( 52). Crippling foreign debt held by developing countries and incurred mostly for huge development projects that may not have been sustainable or in the best interests of improving social justice puts those debtor nations at the mercy of the wealthy countries, but the more important "ecological debt" to the world caused by the degradation of Earth's water, air, soil, climate, and biodiversity by the excess consumption and waste production of the developed world is not paid. The profits of multinational corporations are all too often based on the fact that there is no fullcost pricing. That is, the multinationals do not, in most cases, pay for the degraded Earth capital (depleted and poisoned soils, destabilization of climate, poisoning or wasting of water, depletion of biodiversity, etc.) which is, unfortunately, the basis for much of their profit-not to mention environmental justice and worker safety and health issues. Why is monetary debt considered more important and real than the ecological debt that is destroying the natural commons that is the real basis of life for both humans and all other creatures? He points out that developing countries "continue to fuel the development of richer countries sacrificing their own present and future." They are almost still treated like colonies. Francis suggests "the developed countries ought to help pay this [ecological] debt by significantly limiting their consumption of non-renewable energy and by assisting poorer countries to support policies and programmes of sustainable development" ( 152 ). He points out that "the interests of economic groups which irrationally demolish sources of life should not prevail in dealing with natural resources" ( $\$$ 54). How can it be that the life support systems of Earth are destroyed for the profit of the few, causing suffering for many and for all species of creatures and for future generations?

Powerful special interests trump the common good, over and over, as the repeated failed attempts by the international community to come together to solve the growing global climate change disaster have shown, although perhaps the recent Paris Agreement will prove to be a turning point. There is a desperate need for a paradigm shift that places the common good above the profits of the few; a change that would protect the sacred commons, instead of the "sacred" financial interests of the few. Pope Frances claims that "environmental deterioration and human and ethical degradation are closely linked." For example, when:

economic powers continue to justify the current global system where priority tends to be given to speculation and the pursuit of financial gain, which fail to take the context into account, let alone the effects on human dignity and the natural environment ... whatever is fragile, like the environment, is defenceless before the interests of a deified market [italics added], which become the only rule ( 156 ). 
David Korten (2015) terms this the "sacred money and markets story." When the market is sacred all else is made profane, and some places and communities become sacrifice zones. But, as poet Wendell Berry points out, in actuality, "there are no unsacred places; there are only sacred places and desecrated places" (Berry, 2006, p. 18). It is we who have allowed the holy to become degraded and it is we who have made the profane sacred. Perhaps the cartoon character Pogo was right all those years ago when he said, "We have met the enemy and he is us" (Kelly, 1953).

Francis strongly condemns the "myth of progress," writing that "we find those who doggedly uphold the myth of progress and tell us that ecological problems will solve themselves simply with the application of new technology and without any need for ethical considerations or deep change" ( ( 60), suggesting that increasing resource depletion could well lead to new wars, "albeit under the guise of noble claims" (Ф 57).

Pope Francis feels that we should "become painfully aware, to dare to turn what is happening to the world into our own personal suffering and thus to discover what each of us can do about it” ( 19), as did philosopher Arne Nǽss with his concept of the "ecological self" - an expansion of the psychological sense of self that includes one's ecosystem, the ecosphere, and Earth (Nǽss, 1973, 1993).

\section{The gospel of creation}

Pope Francis affirms that different ways of knowing will be needed if we are to solve our grave human-ecological problems:

science and religion, with their distinctive approaches to understanding reality, can enter into an intense dialogue fruitful for both ... If we are truly concerned to develop an ecology capable of remedying the damage we have done, no branch of the sciences and no form of wisdom can be left out, and that includes religion ( 9 63).

This would also include the unique cultural, artistic, and spiritual riches of all peoples. Francis reiterates Pope John Paul II's claim that people with religious faith "realize that their responsibility within creation, and their duty towards nature and the Creator, are an essential part of their faith" and goes on to proclaim that "it is good for humanity and the world at large when we believers better recognize the ecological commitments which stem from our convictions" (\ 64).

Interestingly, Francis explains that the original creation story in Genesis shows humanity's refusal to accept limits - which is one of the central causes of our global environmental crisis:

9 John Paul II, Message for the 1990 World Day of Peace, 15: AAS 82 (1990), 156. 
human life is grounded in three fundamental and closely intertwined relationships: with God, with our neighbour and with the earth itself ... these three vital relationships have been broken, both outwardly and within us. This rupture is sin. The harmony between the Creator, humanity and creation as a whole was disrupted by our presuming to take the place of God and refusing to acknowledge our creaturely limitations. This in turn distorted our mandate to 'have dominion' over the earth (cf. Gen 1:28), to 'till it and keep it' (Gen 2:15). As a result, the originally harmonious relationship between human beings and nature became conflictual (cf. Gen 3:17-19). († 66)

The pope explains that this "original sin" broke the human relationship with God's laws, his limits (ecological limits in essence), thus our apparent inability to face the limits of physics and ecology in our personal lives and in our industrial, economic, and governmental policies. Ironically, perhaps also our refusal to confront necessary population limits that have been exceeded.

Significantly, Pope Francis responds to the criticism by Lynn White (1967) and many others that the concept of "dominion" from Genesis is a root cause of the "unbridled exploitation of nature." He insists on a "forceful rejection" of the interpretation that being given "dominion over the earth justifies absolute domination over other creatures." He argues strongly that the admonition in Genesis 2:15 to "till and keep" the garden makes it plain that humanity was given the responsibility to care for, protect, and preserve creation.

The earth was here before us and it has been given to us. This allows us to respond to the charge that Judaeo-Christian thinking, on the basis of the Genesis account which grants man "dominion" over the earth (cf. Gen. 1:28), has encouraged the unbridled exploitation of nature by painting him as domineering and destructive by nature. This is not a correct interpretation of the Bible as understood by the Church. Although it is true that we Christians have at times incorrectly interpreted the Scriptures, nowadays we must forcefully reject the notion that our being created in God's image and given dominion over the earth justifies absolute domination over other creatures. The biblical texts ... tell us to "till and keep" the garden of the world (cf. Gen. 2:15). "Tilling" refers to cultivating, ploughing or working, while "keeping" means caring, protecting, overseeing, and preserving. This implies a relationship of mutual responsibility between human beings and nature. Each community can take from the bounty of the earth whatever it needs for subsistence, but it also has the duty to protect the earth and to ensure its fruitfulness for coming generations. ( 97 )

This responsibility for God's earth means that human beings, endowed with intelligence, must respect the laws of nature and the delicate equilibria existing between the creatures of this world ... "he [God] established them for ever and ever; he fixed their bounds and he set a law which cannot pass away (Ps 148:5b-6)” (\ 68).

These are powerful commands that are in complete accordance with the discoveries of science and the recommendations of the Intergovernmental Panel on Climate Change (IPCC, 2014). Most, if not all, of the urgent environmental crises we are 
currently facing are caused by humanity's attempts to violate the laws of physics and the principles of ecology. The significance of Pope Francis's admonitions that God has charged humans with respecting the laws of nature and ecological balances cannot be overstated. If every Christian on Earth followed these admonitions we would be well on our way toward an important paradigm shift.

"The laws found in the Bible dwell on relationships, not only among individuals but also with other living beings" ( $\$$ 68). Here, Francis recognizes that all living beings, including humans, are in relationship—sacred ecosystemic relationship. Francis states emphatically, "clearly, the Bible has no place for a tyrannical anthropocentrism unconcerned for other creatures" ( 68). This is in sharp contrast to criticisms by many scholars that Christian teachings emphasize an anthropocentrism inconsistent with a true environmental ethic (White, 1967). Indeed, he goes on to declare that "we are called to recognize that other living beings have a value of their own in God's eyes," and "to respect creation and its inherent laws." The pope insists that we must respect the laws of physics and the inherent value of each living being, and points out Catholic teachings that "each creature possesses its own particular goodness and perfection" and so "man must therefore respect the particular goodness of every creature, to avoid any disordered use of things"10 (\$ 69). We certainly have not avoided "disordered use of things" at least since the Industrial Revolution, if not since the Agricultural Revolution some 10,000 years ago!

Francis also reminds us that the ancient biblical stories "full of symbolism, bear witness ... that everything is interconnected, and that genuine care for our own lives and our relationships with nature is inseparable from fraternity, justice and faithfulness to others" ( 9 70). He laments our separation from nature: "We were not meant to be inundated by cement, asphalt, glass and metal, and deprived of physical contact with nature" ( $\$ 44)$. He uses the story of Noah to imbue us with hope for renewal, "All it takes is one good person to restore hope!" He goes on to emphasize "the biblical tradition clearly shows that this renewal entails recovering and respecting the rhythms inscribed in nature" ( 7 71), which resonates with the acceptance of the "way of the Tao," the fundamental nature of the flow of the universe (LaFargue, 1992).

\section{Sabbatical year, jubilee year, and gleanings}

Francis gives examples of biblical injunctions for renewal by citing the ancient Old Testament Judaic laws commanding rest on the Sabbath of the week, a sabbatical year of rest for the land every 7 years, and the jubilee year (every 49 years) of general forgiveness as attempts "to ensure balance and fairness in their

10 Catechism of the Catholic Church, 339. 
relationships with others and with the land on which they lived and worked ... it was an acknowledgment that the gift of the earth with its fruits belongs to everyone" ( 91 ). This is a consistent theme throughout the encyclical-the land and its resources belong to everyone, and those who control them must share them. He quotes Leviticus 19:9-10:

When you reap the harvest of your land, you shall not reap your field to its very border, neither shall you gather the gleanings after the harvest. And you shall not strip your vineyard bare, neither shall you gather the fallen grapes of your vineyard; you shall leave them for the poor and for the sojourner ( $\$ 71)$.

Francis slays the "modern myth of unlimited material progress," as he terms it, by arguing that "a fragile world, entrusted by God to human care, challenges us to devise intelligent ways of directing, developing and limiting our power" ( 9 78). This idea is similar to Korten's "sacred money and markets story" - "with enough money our human technologies will liberate us from a dependence on nature" (Korten, 2015, p. 53). So, the pope recognizes sacred limits; just as scientists recognize the reality of limits dictated by the laws of physics and the realities of ecosystem dynamics with complex feedback loops. "In this universe, shaped by open and intercommunicating systems, we can discern countless forms of relationship and participation." He reminds us that the church teaches not only of "the duty to care for nature," but also to "protect mankind from self-destruction" ( $\$$ 79) - a self-destruction that is so obvious to environmental and climate scientists and human ecologists today.

Francis also holds that other living beings are not just objects to be used by humans however they see fit:

subjected to arbitrary human domination ... When nature is viewed solely as a source of profit and gain, this has serious consequences for society. This vision of 'might is right' has engendered immense inequality, injustice and acts of violence against the majority of humanity, since resources end up in the hands of the first comer or the most powerful: the winner takes all ( $($ 82).

"The ultimate purpose of other creatures is not to be found in us ... each creature has its own purpose. None is superfluous ... Soil, water, mountains: everything is, as it were, a caress of God” ( $\$$ 84). David Abram (1996) goes much further, referring to the other creatures of Earth as "the more than human others," contrary to the pope's view that humans have a special status. But Francis's position has moved further toward understanding all creatures as having value in their own right and that all of life is part of a "sacred" interdependent web, or Thomas Berry's (2000) beautiful vision that the universe is a sacred communion, not a disparate group of objects, or even philosopher Martin Buber's (2000) concept of "I-Thou" applied to the other creatures with whom we share this planet. Greek Orthodox Patriarch Bartholomew is quoted by Francis as also saying "accept the world as a sacrament of 
communion"11 ( 9). In a section of the encyclical called "A Universal Communion," Francis claims that "all of us are linked by unseen bonds and together form a kind of universal family, a sublime communion which fills us with a sacred, affectionate and humble respect" ( $₫$ 89). Human humility could certainly be an antidote to our arrogant sense of ownership of all creatures, the land, the air, the water!

Pope Francis reminds us of Pope John Paul II's admonishment, "we cannot interfere in one area of the ecosystem without paying due attention to the consequences of such interference in other areas" ${ }^{\prime 2}$ ( $\left.\$ 131\right)$ — a statement of basic ecological wisdom, and one that "wilderness prophet" John Muir frequently uttered- "When we try to pick out anything by itself, we find it hitched to everything else in the Universe" (Muir, 1911, p. 211). Francis proclaims that "God has joined us so closely to the world around us that we can feel the desertification of the soil almost as a physical ailment, and the extinction of a species as a painful disfigurement" (\$ 89), thus giving us even more responsibility for healing our dysfunctional relationship with the rest of creation. This is almost the same idea as philosopher Arne Nǽss's concept of the ecological self, to include the ecosystems of which we are a part in our sense of self (Nǽss, 1988).

Francis quotes the Canadian Conference of Catholic Bishops, "From panoramic vistas to the tiniest living form, nature is a constant source of wonder and awe. It is also a continuing revelation of the divine." ${ }^{13} \mathrm{He}$ also quotes the Catholic Bishops' Conference of Japan, "To sense each creature singing the hymn of its existence is to live joyfully"14 (\$ 85). He goes on to quote Paul Ricoeur (2009, p. 216)_-"I express myself in expressing the world; in my effort to decipher the sacredness of the world, I explore my own” ( ( 85), evoking William Blake (Gilchrist, 2010):

To see a World in a Grain of Sand,

And a Heaven in a Wild Flower,

Hold Infinity in the palm of your hand,

And Eternity in an hour.

The pope sanctifies the laws of physics and ecology by quoting the Catholic catechism:

God wills the interdependence of creatures. The sun and the moon, the cedar and the little flower, the eagle and the sparrow: the spectacle of their countless diversities and inequalities tells us that no creature is self-sufficient. Creatures exist only in dependence on each other, to complete each other, in the service of each other ${ }^{15}$ ( 86).

11 Halki Summit I, Istanbul, closing remarks “Global Responsibility and Ecological Sustainability” (June 20, 2012).

12 John Paul II, Message for the 1990 World Day of Peace, 6: AAS 82 (1990), 150.

13 Canadian Conference of Catholic Bishops, Social Affairs Commission, pastoral letter "You Love All That Exists ... All Things Are Yours, God, Lover of Life” (October 4, 2003), 1.

14 Catholic Bishops' Conference of Japan, Reverence for Life. A Message for the Twenty-First Century (January 1, 2001), 89.

15 Catechism of the Catholic Church, 340. 
This is a concise affirmation of ecological reality, in both prose and poetry! He points out that "the Spirit of life dwells in every living creature and calls us to enter into relationship with him. Discovering this presence leads us to cultivate the 'ecological virtues” († 88). If all people on Earth felt that all creatures were sacred, we would treat them very differently indeed.

He points out the inequity and social injustice inherent in the huge disparity of resource use by humans, emphasizing that if everyone wasted like the most profligate, we "would destroy the planet," a strong confirmation of the conclusions of ecologists, dramatically illustrated with ecological footprint analyses. As of 2016 "humanity uses the equivalent of 1.6 planets to provide the resources we use and absorb our waste" (Global Footprint Network, 2016).

Francis declares:

A sense of deep communion with the rest of nature cannot be real if our hearts lack tenderness, compassion and concern for our fellow human beings ... Everything is connected. Concern for the environment thus needs to be joined to a sincere love for our fellow human beings and an unwavering commitment to resolving the problems of society ... Moreover, when our hearts are authentically open to universal communion, this sense of fraternity excludes nothing and no one ... Our indifference or cruelty towards fellow creatures of this world sooner or later affects the treatment we mete out to other human beings ... Every act of cruelty towards any creature is contrary to human dignity. ( $(92)$

He quotes the Dominican Bishops' warning about reductionism, "Peace, justice and the preservation of creation are three absolutely interconnected themes, which cannot be separated and treated individually without once again falling into reductionism" 16 ( 92). His support for a holistic, systems-oriented view of the world, rather than the old Cartesian reductionism is apparent. "Everything is related, and we human beings are united as brothers and sisters on a wonderful pilgrimage, woven together by the love God has for each of his creatures and which also unites us in fond affection with brother sun, sister moon, brother river and mother earth" ( 92 ). But he repeatedly and firmly admonishes us to include humans, and especially the poor in our ecological ruminations: "every ecological approach needs to incorporate a social perspective which takes into account the fundamental rights of the poor and the underprivileged" ( 93). Francis declares that the "golden rule of social conduct" and "first principle of the whole ethical and social order" (referring to John Paul II) is the universal right of everyone to the use of the goods necessary for life. "The Christian tradition has never recognized the right to private property as absolute or inviolable, and has stressed the social purpose of all forms of private

16 Conference of Dominican Bishops, pastoral letter "Sobre la Relación del Hombre con la Naturaleza" (January 21, 1987). 
property" (9 93). He quotes John Paul II, "God gave the earth to the whole human race for the sustenance of all its members, without excluding or favouring anyone" 17 and "there is always a social mortgage on all private property"18 (\$ 93).

Francis holds that nature is a collective good belonging to everyone and is likewise the responsibility of all! If everyone using "the commons" of Earth acted responsibly, with care for each other and Earth, the "Tragedy of the Commons" (Hardin, 1968) could be avoided. He explains that if we own property and do not administer it for the good of all, then "we burden our consciences with the weight of having denied the existence of others" ( 95). He reports that the "New Zealand bishops asked what the commandment 'Thou shalt not kill' means when 'twenty percent of the world's population consumes resources at a rate that robs the poor nations and future generations of what they need to survive"' ${ }^{19}$ ( 95 ). What a powerful thought! If the privileged use up so many resources in their excess consumption of goods and energy and despoil distant lands due to extraction of minerals and creation of toxic wastes, causing destabilization of the climate, can we not say that they have violated that commandment?

\section{The human roots of the ecological crisis}

Technological knowledge and the economic resources to use them, what Francis calls "the dominant technocratic paradigm," have given those few who possess them "an impressive dominance over the whole of humanity and the entire world" (\$ 104). He points out the risks created by this power being held by such a small fraction of humanity and that the immense power modern technology has given us has not been matched by an increase in human responsibility, values, and conscience. Pope Francis claims that we do not have an ethics, culture, or spirituality capable of setting limitslimits that we are not even aware of, or are unwilling to admit! The ecological and social dangers of the "paradigm of limitless growth" and the story of "sacred money and markets" are thoroughly treated by Dyball and Newell (2015) and Korten (2015), respectively. Francis quotes Romano Guardini repeatedly, including, "power is never considered in terms of responsibility of choice" (Guardini, 1998, p. 82).

Pope Francis condemns the reductionist paradigm that worships technology resulting in the "deterioration of the environment" ( 107 ) and suggests that by using this "undifferentiated and one-dimensional paradigm" we ignore reality while extracting everything we can "based on the lie that there is an infinite supply of the earth's goods, and this leads to the planet being squeezed dry beyond every limit" ( 1 106). He emphasizes the fact that there are definitely not infinite quantities of

17 John Paul II, Centesimus Annus (encyclical letter, May 1, 1991), 31: AAS 83 (1991), 831.

18 Address to Indigenous and Rural People, Cuilapán, Mexico (January 29, 1979), 6: AAS 71 (1979), 209.

19 New Zealand Catholic Bishops Conference, "Statement on Environmental Issues" (September 1, 2006). 
resources nor energy available and that the negative effects of extraction and use cannot easily be absorbed by natural systems. Additionally, "technological products are not neutral, for they create a framework which ends up conditioning lifestyles and shaping social possibilities along the lines dictated by the interests of certain powerful groups" ( 1 107). That is, the choices for society are diminished because of the dictates of technology. A "technology severed from ethics will not easily be able to limit its own power" ( 136). He decries that we are trapped in a system in which it is acceptable, even expected, that technology will shape lives and determine sociological norms "as dictated by the interests" of a small powerful group. We have become slaves to the interests of technology. "The idea of promoting a different cultural paradigm and employing technology as a mere instrument is nowadays inconceivable ... It has become countercultural to choose a lifestyle whose goals are even partly independent of technology, of its costs and its power to globalize and make us all the same" ( 1 108). He holds that profit, and finance for profit, drives politics and every other aspect of our technological world, with little or no regard for the impacts on human beings or the rest of nature. "The economy accepts every advance in technology with a view to profit, without concern for its potentially negative impact on human beings" ( 109 ). The fallacy of blind belief in future technological fixes is firmly part of the paradigm of limitless growth!

Our global economic system and social institutions are thus enslaved to the needs of technology and do not take care of the needs of the poor, or the environment, showing "no interest in more balanced levels of production, a better distribution of wealth, concern for the environment and the rights of future generations" ( 109$)$. Maximizing profits is the focus! "We fail to see the deepest roots of our present failures, which have to do with the direction, goals, meaning and social implications of technological and economic growth" ( 1 109); technological specialization leads to a failure to see the big picture, "a loss of appreciation for the whole, for the relationships between things ... Life gradually becomes a surrender to situations conditioned by technology, itself viewed as the principal key to the meaning of existence," despite obvious "symptoms which point to what is wrong, such as environmental degradation, anxiety, a loss of the purpose of life and of community living" ( 110$)$.

Francis calls for an alternative world view involving new ways of perceiving and thinking, new policies, more appropriate education, a new "lifestyle and a spirituality which together generate resistance to the assault of the technocratic paradigm" ( | 111). He promotes a holistic, systems approach to solving our deep humanecological problems. "To seek only a technical remedy to each environmental problem which comes up is to separate what is in reality interconnected and to mask the true and deepest problems of the global system" ( 111). In essence, Francis is calling for an earthy spirituality plus the breadth of human ecology and environmental studies: "A science which would offer solutions to the great issues 
would necessarily have to take into account the data generated by other fields of knowledge, including philosophy and social ethics" ( $\mathbb{1 1 0}$ ). "There is a growing awareness that scientific and technological progress cannot be equated with the progress of humanity and history" ( $₫ 113)$.

Declaring that "an authentic humanity, calling for a new synthesis, seems to dwell in the midst of our technological culture, almost unnoticed, like a mist seeping gently beneath a closed door" ( $\$ 112$ ), Francis notes some signs of that new paradigm forming, declaring them as the beginnings of "liberation from the dominant technocratic paradigm" ( 112$)$ :

1. cooperatives of small producers adopting less polluting means of production, and opting for non-consumerist models of life, recreation and community;

2. technology directed primarily to resolving people's concrete problems, truly helping them live with more dignity and less suffering;

3. people desiring to create and contemplate beauty and managing to overcome reductionism through a kind of salvation which occurs in beauty and in those who behold it.

He calls for a switch from a way of life filled with the superficiality of constantly changing technological toys to one filled with wondering about "the purpose and meaning of everything" ( $\$ 113)$, and suggests there is:

[an] urgent need for us to move forward in a bold cultural revolution ... Nobody is suggesting a return to the Stone Age, but we do need to slow down and look at reality in a different way, to appropriate the positive and sustainable progress which has been made, but also to recover the values and the great goals swept away by our unrestrained delusions of grandeur ( $(114)$.

\section{Crisis of anthropocentrism}

Claiming that we currently suffer from an "excessive anthropocentrism," Pope Francis insists that "the time has come to pay renewed attention to reality and the limits it imposes." He admits that Christianity has misunderstood the relationship between humans and the world, claiming a "Promethean vision of mastery over the world, which gave the impression that the protection of nature was something that only the faint-hearted cared about. Instead, our 'dominion' over the universe should be understood more properly in the sense of responsible stewardship" ( 1116$)$. "Once the human being declares independence from reality and behaves with absolute dominion, the very foundations of our life begin to crumble" ( 117 ). This is a remarkable reframing of the Christian concept of dominion, one which incorporates the realities of physics, chemistry, and ecological limits into a responsible stewardship. However, he does warn against biocentrism, describing it as just as imbalanced as anthropocentrism. Most scientists would disagree and 
lean towards biocentrism or ecocentrism as the most objective perspective. Human ecologists would surely include humans firmly within that biocentric, ecocentric, but non-anthropocentric perspective. Critics of Christianity (e.g., White, 1967) have often pointed out its anthropocentric bias, so it is interesting that Pope Francis holds the much more nuanced position of rejecting anthropocentrism and focusing on a broader interpretation of "dominion." He does, however, insist that Christian thought holds human beings above all other creatures, each human being innately worthy of esteem and thus requiring that all persons must have respect for all others. I would extend that respect to all beings in creation, and Pope Francis seems to imply such in several places in Laudato Si. For example, "we are called to recognize that other living beings have a value of their own" and "we are called to respect creation" and "Man must therefore respect the particular goodness of every creature" (\$ 69).

He holds that the ecological crisis is a "sign of the ethical, cultural and spiritual crisis of modernity" and goes on to explain that "we cannot presume to heal our relationship with nature and the environment without healing all fundamental human relationships" ( 119). So he understands our environmental crisis as part of a larger human-ecological crisis, as did Pope Benedict XVI before him (van Tine, 2015). "There can be no renewal of our relationship with nature without a renewal of humanity itself. There can be no ecology without an adequate anthropology" ( $(118)$. He claims that a culture of relativism wherein everything is irrelevant unless it serves one's own interests is the attitude that promotes "the mindset of those who say: Let us allow the invisible forces of the market to regulate the economy, and consider their impact on society and nature as collateral damage" ( 123). He has little faith in politics or the power of law to prevent environmental degradation. "We should not think that political efforts or the force of law will be sufficient to prevent actions which affect the environment because, when the culture itself is corrupt and objective truth and universally valid principles are no longer upheld, then laws can only be seen as arbitrary impositions or

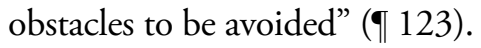

\section{Value of labor}

Pope Francis emphasizes that "Any approach to an integral ecology, ${ }^{20}$ which by definition does not exclude human beings, needs to take account of the value of labour" (\$124). "Work is a necessity, part of the meaning of life on this earth, a path to growth, human development and personal fulfilment" ( $\$ 128)$. Francis promotes and points out the value of small-scale local food production, for example, "there is a great variety of small-scale food production systems which feed the greater part of the world's peoples, using a modest amount of land and producing less waste, be it in small agricultural

20 The phrase "integral ecology" is used by this and other popes to refer to the familiar academic human ecology concept that human welfare should be included in our considerations of environmental health—it's not just about science, it includes social and environmental justice. 
parcels, in orchards and gardens, hunting and wild harvesting or local fishing” ( 1 129), whereas large-scale global industrial agriculture forces small landowners to "sell their land or to abandon their traditional crops." Pope Francis shares that "the Catechism firmly states that human power has limits and that it is contrary to human dignity to cause animals to suffer or die needlessly" (\$130). The use of and experimentation on animals "requires a religious respect for the integrity of creation." 21

\section{Integral ecology}

Francis holds that the study of ecology "entails reflection and debate about the conditions required for the life and survival of society, and the honesty needed to question certain models of development, production and consumption” ( 138 ), and so endorses what seems to me to be the very heart of the academic field of human ecology. He states forcefully that "it cannot be emphasized enough how everything is interconnected." He is firmly against reductionism in science, concluding that "fragmentation of knowledge and the isolation of bits of information can actually become a form of ignorance, unless they are integrated into a broader vision of reality" († 138).

Nature cannot be regarded as something separate from ourselves or as a mere setting in which we live. We are part of nature, included in it and thus in constant interaction with it. Recognizing the reasons why a given area is polluted requires a study of the workings of society, its economy, its behaviour patterns, and the ways it grasps reality. ( 139)

The pope insists:

it is essential to seek comprehensive solutions which consider the interactions within natural systems themselves and with social systems. We are faced not with two separate crises, one environmental and the other social, but rather with one complex crisis which is both social and environmental. Strategies for a solution demand an integrated approach to combating poverty, restoring dignity to the excluded, and at the same time protecting nature ( $(139)$.

This is at its core a statement of the purposes of the academic study of human ecology: basically the same as what Pope Francis and other popes and Catholic scholars have called integral ecology. "Human ecology is inseparable from the notion of the common good, a central and unifying principle of social ethics" († 156).

Francis states that ecosystems "have an intrinsic value independent of their usefulness" ( ( 140). Ecosystems are sacred, according to Pope Francis: "Each organism, as a creature of God, is good and admirable in itself; the same is true of

21 Catechism of the Catholic Church, 2418. 
the harmonious ensemble of organisms existing in a defined space and functioning as a system" ( 140). Humanity is an interdependent part of the sacred wholeness, holiness. And the pope seems to recognize that our very bodies are part of nature, tying us intimately with the rest of creation. "It is enough to recognize that our body itself establishes us in a direct relationship with the environment and with other living beings" ( 1 155). He points out that Jesus was not a dualist, that he was "far removed from philosophies which despised the body, matter and the things of the world" saying that these are "unhealthy dualisms" (ๆ 98).

The pope insists that we must pay "greater attention to local cultures when studying environmental problems," necessitating "a dialogue between scientific-technical language and the language of the people" ( 1 143). Solutions need "to be based in the local culture itself" (\$ 144), respecting the rights of peoples and cultures, paying "special care for indigenous communities and their cultural traditions" ( 1 146). This is a refreshing position in light of the colonial history of the Catholic Church. "For them, land is not a commodity but rather a gift from God and from their ancestors who rest there, a sacred space with which they need to interact if they are to maintain their identity and values" ( 146 ). He also suggests that "social ecology is necessarily institutional, and gradually extends to the whole of society, from the primary social group, the family, to the wider local, national and international communities" ( (142).

\section{Justice between the generations}

The pope argues that ethics demand that there be justice between the generations ( 159). "Leaving an inhabitable planet to future generations is, first and foremost, up to us. The issue is one which dramatically affects us, for it has to do with the ultimate meaning of our earthly sojourn” ( $₫ 160$ ), as recognized by many indigenous peoples throughout the world:

- The notion of the common good also extends to future generations.

- We can no longer speak of sustainable development apart from intergenerational solidarity. Once we start to think about the kind of world we are leaving to future generations, we look at things differently; we realize that the world is a gift which we have freely received and must share with others.

- Intergenerational solidarity is not optional, but rather a basic question of justice, since the world we have received also belongs to those who will follow us.

- The environment is part of a logic of receptivity. It is on loan to each generation, which must then hand it on to the next. ${ }^{22}$

22 Portuguese Bishops' Conference, pastoral letter “Responsabilidade Solidária Pelo Bem Comum” (September 15, 2003), 20. 
Doomsday predictions can no longer be met with irony or disdain. We may well be leaving to coming generations debris, desolation and filth. The pace of consumption, waste and environmental change has so stretched the planet's capacity that our contemporary lifestyle, unsustainable as it is, can only precipitate catastrophes, such as those which even now periodically occur in different areas of the world. The effects of the present imbalance can only be reduced by our decisive action, here and now. We need to reflect on our accountability before those who will have to endure the dire consequences. (Pope Francis, \ 161)

Francis pleads, "let us not only keep the poor of the future in mind, but also today's poor, whose life on this earth is brief and who cannot keep on waiting" ( 1 162). He quotes Pope Benedict XVI, "in addition to a fairer sense of intergenerational solidarity there is also an urgent moral need for a renewed sense of intragenerational solidarity"23 ( (162).

\section{Lines of approach and action}

Pope Francis reminds us that "interdependence obliges us to think of one world with a common plan. Yet the same ingenuity which has brought about enormous technological progress has so far proved incapable of finding effective ways of dealing with grave environmental and social problems worldwide" ( 164 ), despite the fact that "our planet is a homeland and that humanity is one people living in a common home" (1 164). "We know that technology based on the use of highly polluting fossil fuels_-especially coal, but also oil and, to a lesser degree, gas-needs to be progressively replaced without delay” ( $₫ 165)$.

"Although the post-industrial period may well be remembered as one of the most irresponsible in history, nonetheless there is reason to hope that humanity at the dawn of the twenty-first century will be remembered for having generously shouldered its grave responsibilities” ( 1 165), as Thomas Berry predicted with his positive concept of the coming Ecozoic era, an era of ecological understanding and human cooperation with the laws of nature and physics - a time of spiritual renewal and a deepening of both responsibility and life satisfaction (Swimme \& Berry, 1992).

He decries that "recent World Summits on the environment have not lived up to expectations because, due to lack of political will, they were unable to reach truly meaningful and effective global agreements on the environment” (1 166). However, the pope's encyclical may well have influenced the recent international Paris climate agreement. Francis reminds us that the 1992 Earth Summit in Rio proclaimed, "human beings are at the centre of concerns for sustainable development" ${ }^{24}$ and that it reflected the important Stockholm Declaration which "enshrined international

23 Benedict XVI, Message for the 2010 World Day of Peace, 8: AAS 102 (2010), 45.

24 Rio Declaration on Environment and Development (June 14, 1992), Principle 1. 
cooperation to care for the ecosystem of the entire earth, the obligation of those who cause pollution to assume its costs, and the duty to assess the environmental impact of given projects and works" (\$167).

"Reducing greenhouse gases requires honesty, courage and responsibility, above all on the part of those countries which are more powerful and pollute the most" ( $\$ 169)$. Perhaps we see the beginnings of just this with the recent climate agreements between the United States, China, and India related to the 2015 Paris Agreement. Francis warns against proposals to reduce $\mathrm{CO}_{2}$ emissions that would unfairly impact poor countries most in need of development; "further injustice is perpetrated under the guise of protecting the environment" where "the poor end up paying the price" ( 170). He reiterates what the Catholic Bishops of Bolivia stated in 2012, "the countries which have benefited from a high degree of industrialization, at the cost of enormous emissions of greenhouse gases, have a greater responsibility for providing a solution to the problems they have caused." ${ }^{25} \mathrm{He}$ is against carbon credits, fearing that it would lead to a new abusive speculative market. He argues that the top priority is to eliminate extreme poverty and promote social development in poor countries. Poor countries must develop sustainable energy production systems, "but to do so they require the help of countries which have experienced great growth at the cost of the ongoing pollution of the planet" ( 172). He holds that this should be mostly at the expense of the developed countries, for the sake of the whole planet. "The costs of this would be low, compared to the risks of climate change. In any event, these are primarily ethical decisions, rooted in solidarity between all peoples" (\$ 172).

"Enforceable international agreements are urgently needed ... [which] lay down mutually agreed means of averting regional disasters"( 173$)$. "What is needed, in effect, is an agreement on systems of governance for the whole range of so-called 'global commons' ( $\mathbb{1 7 4}$ ), especially because of the weakening of the nation states compared to the power of transnational financial and economic sectors. The pope holds that "it is essential to devise stronger and more efficiently organized international institutions" ( 175). "The same mindset which stands in the way of making radical decisions to reverse the trend of global warming also stands in the way of achieving the goal of eliminating poverty" ( $\$ 175)$. He seems to be in agreement with Naomi Klein, who contends that "any attempt to rise to the climate challenge will be fruitless unless it is understood as part of a much broader battle of worldviews" (Klein, 2014, p. 21). "Our economic system and our planetary system are now at war." She goes on to write, "there is still time to avoid catastrophic warming, but not within the rules of capitalism as they are currently constructed. Which is surely the best argument there has ever been for changing those rules" (ibid., p. 88).

25 Bolivian Bishops' Conference, pastoral letter on the environment and human development in Bolivia "El Universo, don de Dios Para la Vida” (March 2012), 86. 
The people of the world need laws to protect the common good. "How can a society plan and protect its future amid constantly developing technological innovations? One authoritative source of oversight and coordination is the law, which lays down rules for admissible conduct in the light of the common good" (\$177). He holds that a "healthy, mature society" must impose limits. Nature, physics, chemistry, and biology impose real limits. We exceed them at our peril, at the peril of the common good. A wise society would impose legal limits to protect the common good from its own excesses. When nature's limits are exceeded the results are catastrophic, as we are beginning to understand regarding climate change! Cannot humanity govern itself so as to avoid such calamitous outcomes?

A politics concerned with immediate results, supported by consumerist sectors of the population, is driven to produce short-term growth ... governments are reluctant to upset the public with measures which could affect the level of consumption or create risks for foreign investment. The myopia of power politics delays the inclusion of a far-sighted environmental agenda ... True statecraft is manifest when, in difficult times, we uphold high principles and think of the long-term common good ( $(\mathbb{1 7 8 )}$ ).

Francis holds that creation of processes that foster the "common good" are better than attempting to hold on to power.

Providing an example of cooperatives developing sustainable energy for local selfsufficiency, Francis claims that local individuals and groups can cause change even within large systems that are stuck in the old "business as usual" paradigm- "while the existing world order proves powerless to assume its responsibilities, local individuals and groups can make a real difference" ( 179 ). Often, this creative leadership is found in indigenous communities where a deep love for the land, the value of community, and concern for future generations is strong, as illustrated with many contemporary examples by Klein (2014).

Francis affirms standard environmental science recommendations such as increased efficiency, less consumption, less pollution, recycling, and protecting endangered species. The encyclical, at times, reads like an environmental science or ecology textbook. He encourages new forms of cooperation and community organization and diligent public pressure to cause change:

continuity is essential, because policies related to climate change and environmental protection cannot be altered with every change of government. Results take time $\ldots$ in the absence of pressure from the public and from civic institutions, political authorities will always be reluctant to intervene ( $(181)$.

He decries the typical short-term thinking of contemporary politicians. He warns that the potential environmental impacts of projects must not be hidden corruptly "in exchange for favors." He insists that environmental impact assessments should 
be completed before business plans are finalized, and should be part of the process from the beginning, "carried out in a way which is interdisciplinary, transparent and free of all economic or political pressure" (\$ 183).

He advises that all economic projections for projects should realistically include all environmental effects and their costs, and

[a] consensus should always be reached between the different stakeholders, who can offer a variety of approaches, solutions and alternatives. The local population should have a special place at the table; they are concerned about their own future and that of their children, and can consider goals transcending immediate economic interest ... Honesty and truth are needed in scientific and political discussions; these should not be limited to the issue of whether or not a particular project is permitted by law ( $(183)$.

Just because something is legal doesn't necessarily mean it is right and just. "The culture of consumerism, which prioritizes short-term gain and private interest, can make it easy to rubber-stamp authorizations or to conceal information” (\$184). Consideration of the "common good", not just profit, must be a priority in any proposed venture. The pope endorses a "genuine integral development" 26 that works toward the common good with special emphasis on the human rights of the local inhabitants. He supports the precautionary principle, as elucidated in the Rio Declaration of $1992,{ }^{27}$ in order to protect the most vulnerable: "objective and conclusive demonstrations will have to be brought forward to demonstrate that the proposed activity will not cause serious harm to the environment or to those who inhabit it" ( $\$$ 186). This effectively reverses the burden of proof, requiring proof that no serious harm to the environment or to the people would result from proposed development projects. There is a recent encouraging movement to create "B Corporations"-for-profit companies that are certified to uphold rigorous social and environmental justice standards. As of 2016, according to "B Lab," the nonprofit certifying organization, there are more than 1,600 certified B Corporations in 42 countries with the goal of redefining business success (Community of Certified B Corporations, 2016).

\footnotetext{
26 Defined by the Organization of American States as "the general name given to a host of policies that work in tandem to foster sustainable development in both developing and underdeveloped countries" (www.oas.org/en/ topics/integral_development.asp).

27 "Where there are threats of serious or irreversible damage, lack of full scientific certainty shall not be used as a pretext for postponing cost-effective measures," Rio Declaration on the Environment and Development (June 14, 1992), Principle 15.
} 


\section{Politics and economy in dialogue for human fulfillment}

"Today, in view of the common good, there is urgent need for politics and economics to enter into a frank dialogue in the service of life ... The financial crisis of 200708 provided an opportunity to develop a new economy, more attentive to ethical principles ... But the response to the crisis did not include rethinking the outdated criteria which continue to rule the world" ( 1 189) with the possible exception of Iceland where "the government let the banks go bust rather than bail them out at taxpayers' expense; it imposed capital controls on outflows; and it used fiscal transfers to protect the bottom half of the population from disproportionate cuts" (Wade \& Sigurgeirsdottir, 2012, p. 127).

The pope reiterates that "environmental protection cannot be assured solely on the basis of financial calculations of costs and benefits. The environment is one of those goods that cannot be adequately safeguarded or promoted by market forces" (Pontifical Council for Justice and Peace, 2004, p. 470) and he forcefully rejects what he terms the "magical conception of the market" ( 1 190) that promises that all problems are solvable by simply increasing profits! David Korten calls this our "sacred money and markets story." According to him "Time is money. Money is wealth. Material consumption is the path to happiness. Making money creates wealth, drives consumption to increase happiness, and is the defining purpose of individuals, business and the economy" (Korten, 2015, p. 23). Francis asks us:

Is it realistic to hope that those who are obsessed with maximizing profits will stop to reflect on the environmental damage which they will leave behind for future generations? Where profits alone count, there can be no thinking about the rhythms of nature, its phases of decay and regeneration, or the complexity of ecosystems which may be gravely upset by human intervention. Moreover, biodiversity is considered at most a deposit of economic resources available for exploitation, with no serious thought for the real value of things, their significance for persons and cultures, or the concerns and needs of the poor ( 1 190).

Francis points out that higher profits will be made in the long term if the whole picture, including the environment and human well-being, is considered. He promotes what he terms "productive diversification" to use "human ingenuity to create and innovate, while at the same time protecting the environment and creating more sources of employment" instead of "excessive technological investment in consumption and insufficient investment in resolving urgent problems facing the human family". He decries our current focus on finding "ever new ways of despoiling nature, purely for the sake of new consumer items and quick profit" (ף 192). 
Francis pleads for limits to be set before it is too late. He states "we need also to think of containing growth by setting some reasonable limits and even retracing our steps before it is too late" ( 193$)$. It is deeply unethical that ever-increasing levels of consumption and consequent environmental destruction occur "while others are not yet able to live in a way worthy of their human dignity." And these are not unrelated conditions! To the contrary, environmental injustice creates sacrifice zones all over the world in less-developed and developing societies as a result of the insatiable search for higher profits and insatiable consumption in the developed world. The pope declares "the time has come to accept decreased growth in some parts of the world, in order to provide resources for other places to experience healthy growth" ( 1 193). "Live simply so that others may simply live." 28 In their human ecology textbook, Dyball and Newell (2015) refer to the "Goldilocks Principle," a mathematically derived range of human consumption by community that would allow a minimum level of human dignity for all, if the most affluent consume less. They refer to this reduced consumption as "sufficiency," and discuss the possibility of an enriched life with lowered levels of consumption. Pope Francis reminds us that Christianity eschews "obsession with consumption" and, like the teachings of most religions, holds that "less is more" ( $\$$ 222). He proposes a spirituality of personal fulfillment "marked by moderation and the capacity to be happy with little," embracing "simplicity which allows us to stop and appreciate the small things, to be grateful for the opportunities which life affords us, to be spiritually detached from what we possess, and not to succumb to sadness for what we lack” (\ 222).

Francis argues that it is too late for halfway measures that attempt to balance the preservation of nature with financial gain or "the preservation of environment with progress. Halfway measures simply delay the inevitable disaster" (1 194). The contemporary conception of the idea of "progress" needs to be redefined as leaving a better world to future generations and providing a higher quality of life-not by higher levels of consumption. He holds that "people's quality of life actually diminishes-by the deterioration of the environment, the low quality of food or the depletion of resources - in the midst of economic growth" († 194). The concept of "sustainable growth" as opposed to "sustainable development" is often used as a subterfuge to obscure destruction of the environment and abuse of peoples in the name of profitall cloaked in a greenwash of marketing. He holds that environmental protection must be an "integral part of the [sustainable] development process" ( $₫ 141)$.

The principle of the maximization of profits, frequently isolated from other considerations, reflects a misunderstanding of the very concept of the economy ... [for] ... as long as the clearing of a forest increases production, no one calculates the

28 Frequently attributed to either Elizabeth Ann Seton (1774-1821) or Mahatma Gandhi (1869-1948), and although there is little evidence that either ever said it, the truth of the statement is not diminished by not knowing its origin. 
losses entailed in the desertification of the land, the harm done to biodiversity or the increased pollution. In a word, businesses profit by calculating and paying only a fraction of the costs involved ( 1 195).

Ecological and environmental economists have argued for decades for full-cost pricing that would include the costs of the damage to the environment, climate, and health in the cost of all goods and services, thus causing the market to reward good stewardship and punish environmental degradation and creation of sacrifice zones (Costanza et al., 2015; Daly \& Cobb, 1994). As Pope Benedict XVI wrote, only when "the economic and social costs of using up shared environmental resources are recognized with transparency and fully borne by those who incur them, not by other peoples or future generations" ${ }^{29}$ will there be social and environmental justice and equity. There should be a "greater sense of responsibility for the common good from those who wield greater power ... [and] some economic sectors exercise more power than states themselves” ( 1 196).

Pope Francis suggests that we need "a politics which is far-sighted and capable of a new, integral and interdisciplinary approach to handling the different aspects of the crisis" ( 1 197). In effect, he endorses paradigm shifting as called for by human ecologists: "A strategy for real change calls for rethinking processes in their entirety, for it is not enough to include a few superficial ecological considerations while failing to question the logic which underlies present-day culture” († 197).

Francis apologizes for misbegotten mistakes of the past by the Catholic Church with respect to human ecology:

If a mistaken understanding of our own principles has at times led us to justify mistreating nature, to exercise tyranny over creation, to engage in war, injustice and acts of violence, we believers should acknowledge that by so doing we were not faithful to the treasures of wisdom which we have been called to protect and preserve (\$200).

He strongly urges all "religions to dialogue among themselves for the sake of protecting nature, defending the poor, and building networks of respect and fraternity" ( 1201 ), since the majority of people on Earth profess to have religious beliefs. "The gravity of the ecological crisis demands that we all look to the common good, embarking on a path of dialogue which requires patience, self-discipline and generosity, always keeping in mind that 'realities are greater than ideas”" ( 1201 ).

29 Benedict XVI, Caritas in Veritate (encyclical letter, June 29, 2009), 50: AAS 101 (2009), 686. 


\section{Ecological education and spirituality}

The pope believes that "we lack an awareness of our common origin, of our mutual belonging, and of a future to be shared with everyone," and so "A great cultural, spiritual and educational challenge stands before us" (ף 202). Citing Guardini (1998, p. 60), Francis agrees that compulsive consumerism is caused by the technoeconomic paradigm; the gadgets of mass production become the very forms of life itself. "This paradigm leads people to believe that they are free as long as they have the supposed freedom to consume. But those really free are the minority who wield economic and financial power" ( 9 203). "When people become self-centered and self-enclosed, their greed increases. The emptier a person's heart is, the more he or she needs things to buy, own and consume. It becomes almost impossible to accept the limits imposed by reality" ( 1204$)$. Francis quotes Pope Benedict XVI, "the issue of environmental degradation challenges us to examine our lifestyle" 30 and goes on to write that "obsession with a consumerist lifestyle, above all when few people are capable of maintaining it, can only lead to violence and mutual destruction” († 204).

He extolls consumer movements and boycotts that are designed to effect change by forcing businesses to modify their models of production, claiming there is a "great need for a sense of social responsibility on the part of consumers" ( $₫$ 206). He goes on to quote his predecessor, Pope Benedict XVI, "purchasing is always a moral-and not simply economic — act." ${ }^{31}$ Referring to the Earth Charter, he states: "As never before in history, common destiny beckons us to seek a new beginning ... Let ours be a time remembered for the awakening of a new reverence for life, the firm resolve to achieve sustainability, the quickening of the struggle for justice and peace, and the joyful celebration of life," ${ }^{2}$ the same awakening called for by Thomas Berry's Ecozoic era (Berry, 2000). The pope holds that it is wrong that "we fail to set limits on ourselves in order to avoid the suffering of others or the deterioration of our surroundings," but we have "the moral imperative of assessing the impact of our every action and personal decision on the world around us" (ף 208).

He finds that young people in the developed consumer-oriented countries "have a new ecological sensitivity and a generous spirit, and some of them are making admirable efforts to protect the environment" ( 209), yet he warns that they have grown up with the expectations of extreme consumption that will be difficult to change. The pope expresses satisfaction that contemporary environmental education has broadened to include a "critique of the 'myths' of a modernity grounded in a utilitarian mindset (individualism, unlimited progress, competition, consumerism,

30 Benedict XVI, Message for the 2010 World Day of Peace, 11: AAS 102 (2010), 48.

31 Benedict XVI, Caritas in Veritate (encyclical letter, June 29, 2009), 66: AAS 101 (2009), 699.

32 Earth Charter, The Hague (June 29, 2000) (earthcharter.org/discover/the-earth-charter/). 
the unregulated market)" (Dyball \& Newell, 2015; Korten, 2015), and goes on to suggest that "environmental education should facilitate making the leap towards the transcendent which gives ecological ethics its deepest meaning" ( $\mid 210)$.

He holds that the "existence of laws and regulations is insufficient in the long run to curb bad conduct, even when effective means of enforcement are present," and that if those laws are to be effective the majority of the people of a society must be virtuous enough and "adequately motivated to accept them, and personally transformed to respond" to "make a selfless ecological commitment" ( $\$$ 211). "Reusing something instead of immediately discarding it, when done for the right reasons, can be an act of love," and, Francis reminds us, these good efforts will spread and cause change and positive good in the world, even if we are unaware of it! He holds that the family is the primary source of integral ecological education, being where we learn simple respect for each other and for our local ecosystem, and caring for all creatures. It is where we are taught gratitude and sharing and it creates a "culture of shared life and respect for our surroundings" ( $\$ 213$ ). He stresses that "if we want to bring about deep change, we need to realize that certain mindsets really do influence our behaviour," for example, an appreciation for beauty is needed to defeat the paradigm of consumerism; without that appreciation "consumerism will continue to advance, with the help of the media and the highly effective workings of the market" (\$215).

\section{Ecological conversion}

Pope Francis encourages all Christians to develop an "ecological spirituality grounded in the convictions of our faith" ( 216). He admits that Christianity has in the past disassociated "the life of the spirit ... from the body or from nature or from worldly realities" and urges a "communion with all that surrounds us" ( $(216)$. Reflecting on Pope Benedict XVI's exhortation that "the external deserts in the world are growing, because the internal deserts have become so vast," ${ }^{33}$ Francis replies that "the ecological crisis is also a summons to profound interior conversion" ( 1217$)$. He reminds us that the teachings of Saint Francis of Assisi can help us to understand that "a healthy relationship with creation is one dimension of overall personal conversion ... Living our vocation to be protectors of God's handiwork is essential to a life of virtue; it is not an optional or a secondary aspect of our Christian experience" ( $\mathbb{2 1 7}$ ). But, the pope warns that "social problems must be addressed by community networks and not simply by the sum of individual good deeds. The ecological conversion needed to bring about lasting change is also a community conversion" ( $₫$ 219) that requires gratitude for creation and "entails a loving awareness that we are not disconnected from the rest of creatures, but joined in a splendid universal communion” ( $₫ 220$ ),

33 Benedict XVI, "Homily for the Solemn Inauguration of the Petrine Ministry" (April 24, 2005): AAS 97 (2005), 710 . 
or as self-described gaeologian and Catholic priest and professor Thomas Berry put it, "the universe is a communion of subjects rather than a collection of objects" (Swimme \& Berry, 1992, p. 243).

Pope Francis asks for all Christians to undergo a sacred ecological conversion that "can inspire us to greater creativity and enthusiasm in resolving the world's problems" ( 1220 ). This conversion, according to the pope, would include

the awareness that each creature reflects something of God and has a message to convey to us ... that Christ has taken unto himself this material world and now, risen, is intimately present to each being ... [and] God created the world, writing into it an order and a dynamism that human beings have no right to ignore ( 1221 ).

Francis asks all Christians to "recognize and to live fully this dimension of their conversion," giving the invocation:

May the power and the light of the grace we have received also be evident in our relationship to other creatures and to the world around us. In this way, we will help nurture that sublime fraternity with all creation which Saint Francis of Assisi so radiantly embodied ( $\boldsymbol{\Phi} 221)$.

Could not all peoples of the world take on a similar conversion within the framework of their world views or religious cosmologies? A conversion to the realization that all of life is sacred and interconnected, that we are all part of that hallowed interdependent web of existence, that Earth, and her creatures, including people, are holy and worthy of respect and care? That we must honor the Tao by learning to live in harmony with it? Could this conversion even encompass the growing numbers of the non-religious, or atheists? A conversion to the realization that the very existence of all living creatures, Earth, its ecosystems, its peoples, the biochemistry of life, the amazing ecological interdependencies, are all breathtaking, and should be honored and preserved? A deep awareness of the responsibility that being a part of this profoundly interconnected web requires cooperation to maintain it?

\section{Joy and peace, civic and political love}

Francis reminds us that "once we lose our humility, and become enthralled with the possibility of limitless mastery over everything, we inevitably end up harming society and the environment" ( 1224$)$ and:

inner peace is closely related to care for ecology and for the common good because, lived out authentically, it is reflected in a balanced lifestyle together with a capacity for wonder which takes us to a deeper understanding of life ... [and so] integral ecology includes taking time to recover a serene harmony with creation (\ 225). 
He applauds the act of giving thanks before a meal, for, among other things, "it strengthens our feeling of gratitude for the gifts of creation; it acknowledges those who by their labours provide us with these goods" ( $₫ 227$ ).

The pope extends the Christian tradition of fraternal love to all of creation, "gratuitousness ${ }^{34}$ inspires us to love and accept the wind, the sun and the clouds, even though we cannot control them. In this sense, we can speak of a 'universal fraternity" ( ( 228). "An integral ecology is also made up of simple daily gestures which break with the logic of violence, exploitation and selfishness. In the end, a world of exacerbated consumption is at the same time a world which mistreats life in all its forms" ( ( 230).

Francis holds that social love is the key to causing positive change and sustainable development.

Love for society and commitment to the common good are outstanding expressions of a charity which affects not only relationships between individuals but also "macrorelationships, social, economic and political ones," ${ }^{35}$ social love moves us to devise larger strategies to halt environmental degradation and to encourage a 'culture of care’ which permeates all of society ( $(231)$.

Around these community actions, relationships develop or are recovered and a new social fabric emerges. Thus, a community can break out of the indifference induced by consumerism ... These community actions, when they express self-giving love, can also become intense spiritual experiences ( $\$ 232)$.

\section{Comparison with the philosophy of Deep Ecology}

The philosophy of Deep Ecology is in many ways similar to Pope Francis's main points. Here is the Deep Ecology Platform, as articulated by philosophers Arne Nǽss and George Sessions in 1984 (Nǽss, 1993):

1. The well-being and flourishing of human and non-human life on Earth have value in themselves (synonyms: intrinsic value, inherent worth). These values are independent of the usefulness of the non-human world for human purposes.

2. Richness and diversity of life forms contribute to the realization of these values and are also values in themselves.

3. Humans have no right to reduce this richness and diversity except to satisfy vital needs.

34 Something freely given or received without payment or obligation.

35 Benedict XVI, Caritas in Veritate (encyclical letter, June 29, 2009) 2: AAS 101 (2009), 642. 
4. The flourishing of human life and cultures is compatible with a substantially smaller human population. The flourishing of non-human life requires a smaller human population.

5. Present human interference with the non-human world is excessive, and the situation is rapidly worsening.

6. Policies must therefore be changed. These policies affect basic economic, technological, and ideological structures. The resulting state of affairs will be deeply different from the present.

7. The ideological change will be mainly that of appreciating life quality (dwelling in situations of inherent value) rather than adhering to an increasingly higher standard of living. There will be a profound awareness of the difference between bigness and greatness.

8. Those who subscribe to the foregoing points have an obligation directly or indirectly to try to implement the necessary changes.

The main discrepancy is with point number 4: Human population. Catholic teachings do not support efforts to limit the human population by birth control, each potential life being a gift from God. However, the other tenets of Deep Ecology resonate strongly with the message of Pope Francis in his powerful encyclical. Francis also adds admonitions to ecological spiritual renewal based on religious belief and Catholic moral teachings. But perhaps there can also be ecological spiritual renewal outside traditional religious practice.

\section{Conclusions}

Laudato $S i$ ' is a powerful and well-reasoned paean to environmental sanity from one of the most important moral voices of the world. It is a comprehensive, multifaceted argument for applied environmental ethics for individuals, corporations, countries, and the world community based not only on Catholic religious traditions and teachings but also grounded in scientific fact. Pope Francis calls for an ecological spiritual renewal that can be applied to Catholics, Protestants, Jews, Muslims, Buddhists, or to the non-religious. He forcefully argues for an integral ecology that recognizes humans as part of the interdependent web of existence which includes all of creation, the plants, animals, and ecosystems, all of which he considers sacred. He supports the necessity of using all different ways of knowing, including religion and science, sociology, economics, and the arts, to solve our existential environmental crises. He is passionate and convincing in his arguments for caring for our common home. Human ecologists have found an ally in Pope Francis.

Pope Francis ends his encyclical "Care for Creation" with two powerful prayers: A Prayer For Our Earth and A Prayer in Union With Creation. Here, in conclusion, are some excerpts: 
Bring healing to our lives,

that we may protect the world and not prey on it,

that we may sow beauty,

not pollution and destruction.

Touch the hearts

of those who look only for gain

at the expense of the poor and the earth.

Teach us to discover the worth of each thing,

to be filled with awe and contemplation,

to recognize that we are profoundly united

with every creature.

Awaken our praise and thankfulness

for every being ...

Give us the grace to feel profoundly joined to everything that is.

Enlighten those who possess power and money

that they may avoid the sin of indifference,

that they may love the common good,

advance the weak,

and care for this world in which we live.

The poor and the earth are crying out.

\section{Acknowledgments}

A thank you to Rob Dyball for encouraging me to complete this treatise and for scheduling a round table discussion on it during the XXIst Society for Human Ecology conference. Thanks to the panelists who deeply enriched the dialogue: John Schooneveldt, The Australian National University, Carleton (Bruin) Christensen, The Australian National University, Carla Jimena, University of the Philippines. Thanks to my wife, Lucy van Tine, for converting all of the encyclical page number references to paragraph numbers. And a big thanks to Tracy Harwood for her thorough technical edit of the manuscript. This paper is dedicated to the memory of my dear friend, colleague, and mentor, John "Jack" Dougher, who introduced me to the work of Thomas Berry and with whom I spent countless wonderful hours in dialogue about the issues addressed in this paper. He also encouraged me to continue "the great work." Thank you, Jack. 


\section{References}

Abram, D. (1996). The spell of the sensuous: Perception and language in a more-thanbuman world. New York, NY: Pantheon.

Benedict XVI. (2014). The garden of God: Toward a human ecology. Washington, DC: The Catholic University of America Press.

Berry, T. (2000). The great work: Our way into the future. New York, NY: Broadway Books.

Berry, W. (2006). Given. Berkeley, CA: Counterpoint Press.

Buber, M. (2000). I and thou (R. G. Smith, Trans.). New York, NY: Scribner.

Chryssavgis, J. (Ed.). (2012). On earth as in heaven: Ecological vision and initiatives of Ecumenical Patriarch Bartholomew. New York, NY: Fordham University Press.

Community of Certified B Corporations. (2016). What are B Corps? Retrieved from www.bcorporation.net/what-are-b-corps

Costanza, R., Cumberland, J. H., Daly, H., Goodland, R., Norgaard, R. B., Kubiszewski, I., \& Franco, C. (2015). An introduction to ecological economics (2nd ed.). Boca Raton, FL: CRC Press.

Dalai Lama XIV. (n.d.). Universal responsibility and the environment. Retrieved from www.dalailama.com/messages/environment/universal-responsibility

Daly, H. E., \& Cobb, J. B. (1994). For the common good. Boston, MA: Beacon Press.

Dyball, R., \& Newell, B. (2015). Understanding human ecology: A systems approach to sustainability. New York, NY: Routledge.

Food and Agricultural Organization (FAO). (n.d.). SAVE FOOD: Global Initiative on Food Loss and Waste Reduction. Retrieved from www.fao.org/save-food/ resources/keyfindings/en/

Francis. (2015). Laudato Si' (Praise be to you) (encyclical letter). San Francisco, CA: Ignatius Press.

Francis of Assisi. (1914). The canticle of the sun called also the canticle of the creatures. Harry Alfred Fowler.

Gilchrist, A. (2010). Life of William Blake with selections from his poems and other writings. New York, NY: Cambridge University Press. 
Global Footprint Network. (2016). World footprint. Retrieved from www.footprint network.org/en/index.php/GFN/page/world_footprint/

Guardini, R. (1998). The end of the modern world (9th ed.). Wilmington, DE: ISI Books.

Hardin, G. (1968). The tragedy of the commons. Science, 162(3859), 1243-1248. doi.org/10.1126/science.162.3859.1243

Heschel, A. (1976). God in search of man: A philosophy of Judaism. New York, NY: Farrar, Straus and Giroux.

IPCC (Intergovernmental Panel on Climate Change). (2014). Climate change 2014: Synthesis report. Contribution of Working Groups I, II, and III to the Fifth Assessment Report of the Intergovernmental Panel on Climate Change. Geneva: IPCC. Retrieved from www.ipcc.ch/pdf/assessment-report/ar5/syr/SYR_AR5_ FINAL_full_wcover.pdf

Kelly, W. (1953). The Pogo papers. New York, NY: Simon \& Schuster.

Klein, N. (2014). This changes everything: Capitalism vs. the climate. New York, NY: Simon \& Schuster.

Korten, D. C. (2015). Change the story, change the future: A living economy for a living Earth. Oakland, CA: Berrett-Koehler Publishers.

LaFargue, M. (1992). The Tao of the Tao Te Ching: A translation and commentary. Albany, NY: State University of New York Press.

Lerner, S. (2010). Sacrifice zones: The front lines of toxic chemical exposure in the United States. Cambridge, MA: MIT Press.

Lyons, O. (1994). An Iroquois perspective. In C. Vecsey \& R. W. Venables (Eds.), American Indian environments: Ecological issues in Native American history (pp. 173-174). Syracuse, NY: Syracuse University Press.

Muir, J. (1911). My first summer in the Sierra. Boston, MA: Houghton Mifflin.

Nǽss, A. (1973). The shallow and the deep, long-range ecology movement: A summary. Inquiry: An Interdisciplinary Journal of Philosophy and the Social Sciences, 16(1-4), 95-100. doi.org/10.1080/00201747308601682

Nǽss, A. (1988). Self realization: An ecological approach to being in the world. In J. Seed, J. Macy, \& P. Fleming (Eds.), Thinking like a mountain. New Society.

Náss, A. (1993). Ecology, community, and lifestyle: Outline of an ecosophy (D. Rothenberg, Trans.). New York, NY: Cambridge University Press. 
Osbaldiston, R., \& Sheldon, K. M. (2002). Social dilemmas and sustainability: Promoting peoples' motivation to "cooperate with the future." In P. Schmuck \& W. P. Schultz (Eds.), Psychology of sustainable development. Boston, MA: Kluwer Academic Publishers. doi.org/10.1007/978-1-4615-0995-0_3

Pontifical Council for Justice and Peace. (2004). Compendium of the social doctrine of the church. Retrieved from www.vatican.va/roman_curia/pontifical_councils/ justpeace/documents/rc_pc_justpeace_doc_20060526_compendio-dott-soc_ en.html

Ricoeur, P. (2009). Philosophie de la volonté 2: Finitude et culpabilité. Paris.

Seed, J., Macy, J., Fleming, P., \& Nǽss, A. (2007). Thinking like a mountain: Towards a council of all beings. New Catalyst Books.

Sinclair, U. (1994). I, candidate for governor: And how I got licked (Reprint ed.). Berkeley and Los Angeles, CA: University of California Press.

Southern Baptist Convention. (n.d.). A Southern Baptist declaration on the environment and climate change. Southern Baptist Environment \& Climate Initiative. Retrieved from web.archive.org/web/20101017203832/http:/www. baptistcreationcare.org/node/ 1

Swimme, B., \& Berry, T. (1992). The universe story: From the primordial flaring forth to the Ecozoic era-A celebration of the unfolding of the cosmos. San Francisco, CA: Harper.

van Tine, R. (2000, May). Gaeaphobia: Ecophobia, ecomania and "otherness" in the late 20th century. Gatherings: Journal for the International Community for Ecopsychology (Spring). Retrieved from www.ecopsychology.org/journal/ gatherings $2 /$ robin.htm

van Tine, R. (2015). Review of the book The garden of God: Toward a human ecology, by Benedict XVI. Human Ecology Review, 21(2), 173-180.

Wade, R. H., \& Sigurgeirsdottir, S. (2012). Iceland's rise, fall, stabilisation and beyond. Cambridge Journal of Economics, 36(1), 127-144. doi.org/10.1093/cjel ber038

White, L. (1967). The historical roots of our ecological crisis. Science, 155(3767), 1203-1207. doi.org/10.1126/science.155.3767.1203 
This text is taken from Human Ecology Review, Volume 23, Number 1, 2017, published 2017 by ANU Press, The Australian National University, Canberra, Australia.

dx.doi.org/10.22459/HER.23.01.2017.08 